\title{
Spatial patterns of spring meroplankton along environmental gradients in a sub-Arctic fjord
}

\author{
Helena Kling Michelsen*, Einar Magnus Nilssen, Torstein Pedersen, Marit Reigstad, \\ Camilla Svensen
}

Department of Arctic and Marine Biology, UiT The Arctic University of Norway, Tromsø, Norway

\begin{abstract}
The spatial patterns in abundance and composition of benthic invertebrate larvae (meroplankton), the correlation between these patterns and environmental variables (temperature, salinity and chl a) and the relative abundance of meroplankton in the mesozooplankton community were investigated in the sub-Arctic Porsangerfjord, Norway $\left(70^{\circ} \mathrm{N}\right)$. Zooplankton samples and CTD-profiles were collected at 17 stations along the fjord in April 2013. A total of 32 morphologically different larval types belonging to 8 phyla were identified. Meroplankton were found at all stations, and their community and abundance differed significantly along the fjord. Meroplankton abundance in the inner and outer parts of the fjord was low and was dominated by Gastropoda and Echinodermata. The greatest numbers were recorded in shallow bays and the middle part of the fjord where Cirripedia and Polychaeta were dominant. Meroplankton contributed significantly to the mesozooplankton community in the bays (30 to $90 \%$ ) and mid-fjord (13 to $48 \%$ ) areas. These changes in community structure were attributed to spatial gradients in environmental variables such as chl $a$, salinity and temperature. The different communities suggested a seasonal succession in reproductive events from the fjord mouth toward the head. Considering that spring is an important season for reproduction in pelagic organisms, meroplankton may play a role in the pelagic ecosystem of high-latitude fjords as grazers and prey. Furthermore, the spatial dynamics and reproductive timing of benthic and holoplanktonic organisms are sensitive to local hydrographical features, illustrating their sensitivity to changing environments.
\end{abstract}

KEY WORDS: Benthic invertebrate larvae $\cdot$ Zooplankton $\cdot$ Advection $\cdot$ Distribution $\cdot$ High latitude Porsangerfjord

\section{INTRODUCTION}

Fjords and estuaries are complex coastal systems, characterized by sharp gradients in environmental variables such as temperature, salinity and primary production. Typically, water masses at the mouths of fjords are influenced by surrounding coastal waters and become less saline and cooler toward the head due to the influence of rivers, runoff from land, limited mixing and cool inland temperatures (Wassmann et al. 1996, Eilertsen \& Skarðhamar 2006). Such gradients are often reflected in the spatial community structure, abundance and biomass of both

${ }^{*}$ Corresponding author: helena.k.michelsen@uit.no planktonic and benthic organisms (Basedow et al. 2004, Meerhoff et al. 2014, Fuhrmann et al. 2015). Furthermore, fjords located at high latitudes are influenced by a strong seasonality in photoperiod, temperature and spring bloom (Eilertsen et al. 1981, Eilertsen \& Skarðhamar 2006, Eilertsen \& Frantzen 2007), which in turn influence the lifecycles and developmental durations of organisms residing there.

Many benthic invertebrates have an indirect development by producing pelagic larvae called meroplankton. Reproductive timing, output and developmental duration of these invertebrates are finely tuned to environmental variables to ensure that

() The authors 2017. Open Access under Creative Commons by Attribution Licence. Use, distribution and reproduction are unrestricted. Authors and original publication must be credited. 
spawning and egg hatching occur during the optimal time of highest fertilization success, larval survival or when energy levels are high enough for further adult survival (Thorson 1950, Mileikovsky 1971). Due to the temporally and spatially variable nature of environmental variables at high latitudes, benthic invertebrates display a strong annual timing of these lifecycle events (Kuklinski et al. 2013, Silberberger et al. 2016, Stübner et al. 2016, Michelsen et al. 2017). Reproduction at high latitudes occurs mainly in spring and summer and often coincides with increasing chlorophyll a (chl a) concentrations, warming temperatures and increasing day length (Kwasniewski et al. 2013, Silberberger et al. 2016, Stübner et al. 2016, Michelsen et al. 2017). The exact timing of larval or gamete release depends on the species and their biogeographical origin and may vary between taxa and species as they respond differently to the environmental variability experienced (Monro \& Marshall 2015).

Some meroplankters feed during their planktonic stage (i.e. planktotrophic), as herbivores, detritivores or omnivores; others are non-feeding (i.e. lecithotrophic), nourishing themselves on yolk and lipids derived from the parent (Mileikovsky 1971, Levin \& Bridges 1995). Planktotrophic larvae are primarily spawned in connection with the onset and peak primary production period in spring and summer. In temperate, sub-Arctic and Arctic coastal waters, benthic invertebrate larvae are found in high numbers in the water column during these seasons and often dominate numerically in the zooplankton community (Smidt 1979, Falk-Petersen 1982, Kuklinski et al. 2013, Stübner et al. 2016). Thus, they may play an important role in the pelagic ecosystem as grazers, predators, prey and competitors.

The time spent by propagules in the water column can last from hours to months before they settle on the seafloor as juveniles (Thorson 1950). The duration a propagule stays in the water column varies between species and taxa, often depending on the environmental factors encountered. In fjord and estuaries, the spatial composition, abundance and biomass of meroplankton and holoplankton (permanent members of the pelagic) are tightly coupled with hydrodynamic features (Basedow et al. 2004). Although meroplankton are capable of vertical migration, their ability to determine their horizontal distribution is limited (Shanks 1995). Their distribution depends on water currents in the area of release and their behavioral traits. Consequently, larvae may be either advected or retained close to the release site. Recent evidence indicates that local retention may be a common feature for many pelagic larvae (Lamare \& Barker 1999, Levin 2006). The spatial pattern of meroplankton is also dependent on the local species composition and abundance of reproducing adults. Therefore, knowledge about pelagic life stages is crucial in understanding the population dynamics of benthic invertebrates and may be used in developing optimal marine protected areas (Shanks et al. 2003), understanding the spread of invasive species (Neubert \& Caswell 2000, Pedersen et al. 2006) and the potential poleward expansion of benthic populations with warming sea temperatures (Renaud et al. 2015).

The spatial patterns and dynamics of the whole meroplankton community at high-latitude fjord and estuarine sites have been the focus of historic studies (e.g. Thorson 1936, Mileikovsky 1968, Andersen 1984). Recent studies investigating their spatial structure at high latitudes have focused on the link between hydrography and larval distribution in fjords with high river discharges (Fetzer \& Deubel 2006, Meerhoff et al. 2014), in coastal shelf areas (Clough et al. 1997, Silberberger et al. 2016) and in open water (Schlüter \& Rachor 2001). To our knowledge, no detailed spatial studies have focused on meroplankton dynamics in high-latitude fjords or estuaries with strong spatial gradients in environmental variables during spring.

The sub-Arctic Porsangerfjord (northern Norway) exhibits strong temporal and spatial variation in hydrography and hydrodynamics. There is a strong influence of warm coastal water at the mouth, while the inner part of the fjord contains a semi-enclosed basin with an Arctic environment and ecosystem. These spatial gradients make the fjord an interesting case study for understanding the spatial and temporal dynamics of meroplankton at high latitudes. The fjord supports high benthic production and biomass (Fuhrmann et al. 2015) and the environmental variables have been shown to be important to both the holoplanktonic and benthic adult community structure within the fjord (Fuhrmann et al. 2015, Priou 2015). Moreover, a recent study on the seasonal dynamics of meroplankton at 2 stations within the fjord showed that meroplankton dynamics in the water column followed a strong seasonal trend, where spring and summer had the highest total abundance of meroplankton as well as relative abundance of meroplankton in the zooplankton community (Michelsen et al. 2017).

Because spring is an important spawning time for benthic invertebrates, our main objectives were to (1) investigate the spatial patterns in abundance and composition of spring meroplankton within the fjord 
on a high spatial grid, (2) identify possible environmental variables responsible for spatial patterns in meroplankton and (3) investigate the relative abundance of meroplankton in the mesozooplankton community within the fjord.

\section{MATERIALS AND METHODS}

\section{Study area}

Porsangerfjord is located in the northernmost part of Norway $\left(70.0\right.$ to $71.0^{\circ} \mathrm{N}, 25$ to $26.5^{\circ} \mathrm{E}$ ) adjacent to the Barents Sea (Fig. 1). It is a broad fjord (15 to $20 \mathrm{~km}$ ) with a length of $100 \mathrm{~km}$ and a mean depth of $200 \mathrm{~m}$. There is limited freshwater runoff from land and, based on bathymetry and water exchange, the fjord is separated into 3 basins: Outer, Middle (Mid)

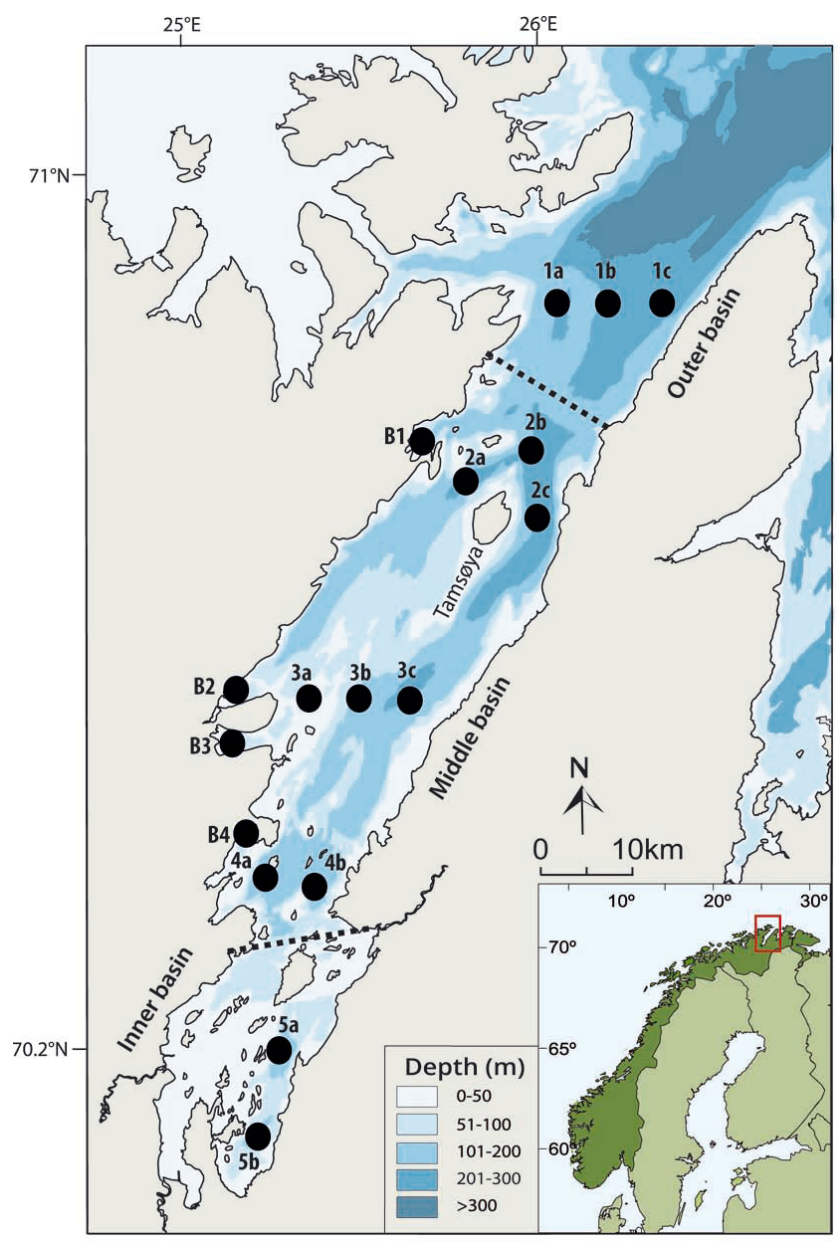

Fig. 1. Location of stations sampled in April 2013 in Porsangerfjord, Norway. Stippled lines: fjord sills that delineate each basin and Inner (Svendsen 1991, Myksvoll et al. 2012, Mankettikkara 2013). A shallow $60 \mathrm{~m}$ sill approximately $30 \mathrm{~km}$ from the head of the fjord delineates the Inner basin, the Mid basin is separated from the outer fjord by a deep sill at $180 \mathrm{~m}$ and a large island (Tamsøya), while the Outer basin is open to the coast (Myksvoll et al. 2012). The Outer and Mid basins are classified as semi-enclosed with frequent exchange of deep water with the Norwegian Coastal Current (NCC) and Atlantic water (Svendsen 1995, Wassmann et al. 1996, Eilertsen \& Skarðhamar 2006). The Inner basin has little contact with the coast and is characterized as Arctic. It contains a unique Arctic community, is ice-covered in late winter and early spring and temperatures reach as low as $-1.7^{\circ} \mathrm{C}$ (Wassmann et al. 1996, Sunnset 2008). The circulation patterns in the fjord are influenced by the prevailing wind direction and strength, which are strongest in mixed waters during winter and spring (Svendsen 1991, 1995). The prevailing wind direction during these seasons is northerly and southerly, respectively (Wassmann et al. 1996). Southerly winds, in combination with rotational effects, result in a main circulation pattern within the fjord that forms a strong outflowing current with winter cooled fjordwaters along the eastern side and an incurrent of warmer coastal waters along the western side (Myksvoll et al. 2012). In the Outer basin, a large eddy is often formed, mixing water from the NCC and the cold water originating from within the fjord (Pedersen et al. 2005, Myksvoll et al. 2012).

\section{Plankton sampling and hydrography}

The mesozooplankton community was sampled at 17 stations between 11 and 17 April 2013. Stations were arranged in transects across the fjord: one transect located in the Outer basin (Stns 1a, 1b, 1c), 3 transects in the Mid basin (Stns 2a, 2b, 2c, 3a, 3b, 3c, $4 a, 4 b), 2$ stations in the Inner basin (Stns 5a, 5b), and 4 stations in bays (Stns B1, B2, B3, B4) along the western side of the Mid basin (Fig. 1, Table S1 in the Supplement at www.int-res.com/articles/suppl/b026 p185_supp.pdf). Each station was sampled using a WP2 net with $180 \mu \mathrm{m}$ mesh size (Hydrobios, Kiel; $0.57 \mathrm{~m}^{2}$ mouth opening) and a filtering cod-end. The net was towed vertically from approximately $5 \mathrm{~m}$ above the seafloor to the sea surface at a speed of $0.5 \mathrm{~m} \mathrm{~s}^{-1}$. Between 1 and 3 hauls were taken at each station, filtering a volume of 29 to $214 \mathrm{~m}^{3}$ (Table S1). Samples were fixed with $4 \%$ buffered formaldehyde in seawater. 
A CTD-profile of the water column (SBE9; Sea-Bird Electronics) was taken at each station prior to plankton sampling to record temperature, salinity and fluorescence. In situ fluorescence obtained by the CTD profiles was calibrated to provide an approximate chl a concentration. Water samples for determination of chl a concentration were collected at Bay Stns B1, B2, B3 and B4 (Fig. 1, Table S1). Water was collected at $0,10,20,30,40$ and $60 \mathrm{~m}$ and followed procedures described in Michelsen et al. (2017). In contour maps, temperature and salinity at the surface and seafloor together with the depth-integrated chl a concentration at each station were interpolated and smoothed using data interpolate variational analysis (DIVA) gridding to extrapolate missing data points across the whole fjord using Ocean Data View software (Schlitzer 2012).

\section{Zooplankton enumeration and identification}

Zooplankton samples with a high concentration of organisms were split in 1/2 to 1/8 using a Folsomsplitter prior to dilution. The samples were diluted to a volume of between 200 and $2000 \mathrm{ml}$. Before subsampling, organisms larger than $5 \mathrm{~mm}$ (macrozooplankton) were removed and counted. Subsample aliquots of 3 to $5 \mathrm{ml}$ from a randomized sample were extracted using a Finnpipette with the tip cut at $4 \mathrm{~mm}$ diameter. The main planktonic components (meroplankton and holoplankton) were identified and counted. Randomized subsample aliquots were extracted until approximately 300 individuals of each zooplankton component were counted using a stereomicroscope (Leica MZ16) equipped with a calibrated micrometer (see Michelsen et al. 2017 for details). Meroplankton were identified to the lowest level possible using available identification keys. When identified larvae belonging to a given genus is composed of one species they are abbreviated with sp. whilst a genus comprised of several species is abbreviated as spp. Unidentifiable larvae were pooled according to their respective higher taxon or developmental type (e.g. Gastropoda veliger, trochophore). Holoplankton were counted as a whole and not identified to a lower taxonomic level.

\section{Data analysis}

Abundance is presented as ind. $\mathrm{m}^{-3}$, based on the assumption of $100 \%$ filtering efficiency. The nonparametric Kruskal-Wallis analysis (K-W) was used to test the similarity between several groups of samples (e.g. basins), followed by a Dunn test to assess similarity between each group. Meroplankton abundance was fourth-root transformed prior to multivariate statistics in order to reduce the influence of highly abundant taxa and to distinguish subtle differences in community composition. The Bray-Curtis dissimilarity coefficients were calculated for meroplankton to assess differences in meroplanktonic abundance and composition between stations. An average hierarchical linkage dendrogram was produced using the calculated Bray-Curtis matrix and cut at significant clusters, to indicate similar communities in meroplankton structure. To assess whether the clusters in the dendrogram were supported by the dataset, p-values for each cluster were calculated through a multi-scale bootstrap re-sampling procedure using 9999 re-samplings. In order to reveal which meroplanktonic taxa were responsible for the dissimilarity in the Bray-Curtis matrix and the defined geographical areas in the fjord, SIMPER analysis was performed on fourth-root transformed data. The cut-off for low contribution species was fixed at $75 \%$. A multivariate non-parametric permutation ANOVA (PERMANOVA) was used to test the difference in taxonomic assemblage of meroplankton between the defined geographical areas (Anderson 2001). Calculation of the pseudo- $F$ and p-values was based on 9999 permutations using the Bray-Curtis matrix. To assess the correlation and relationship between meroplankton distribution patterns and environmental variables at the different stations, a constrained canonical correspondence analysis (CCA) was performed. A forward selection method using permutation tests was performed on all environmental variables recorded (mean seafloor temperature and salinity, mean surface temperature and salinity, depth at station and mean surface chl a) to select the variables which significantly explained the variance in the meroplankton data. The most significant variable was included in each selection round until none added significant explanation to the variation in the meroplankton data (9999 permutations, p < 0.05). Only significant environmental variables were included in the CCA ordination plots. The significance of environmental variables and the chosen axis was assessed using an ANOVA permutation test with 9999 permutations. Species and stations were constrained onto a chi-squared matrix based on 2 environmental variables. Only taxa contributing to $>1 \%$ of the results are presented in the CCA ordination with full names. All null hypotheses in the study were rejected at $\mathrm{p}<0.05$. The multi-scale bootstrap 
re-sampling, PERMANOVA, SIMPER and CCA analysis were performed using R software, version 2.14.2 (R Development Core Team 2012), and the 'vegan' (Oksanen 2015) and 'pvclust' (Suzuki \& Shimodaira 2015) libraries.

\section{RESULTS}

\section{Environmental gradients along the fjord}

There were differences in water mass properties between the 3 basins. The Outer basin had warmer and more saline water at both the surface $\left(3^{\circ} \mathrm{C}\right.$ and $34.3)$ and seafloor $\left(5.5^{\circ} \mathrm{C}\right.$ and 34.8$)$, where the seafloor was characteristic of the NCC $\left(2\right.$ to $5^{\circ} \mathrm{C}$ and salinity >34.9) (Fig. 2a-d). Chl a concentrations were

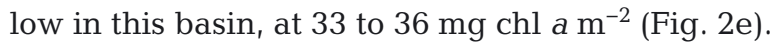

The Mid basin including the Bays displayed a strong gradient, with temperature and salinity decreasing from the mouth to the head of the fjord. The surface temperature and salinity at Stns $2 \mathrm{a}-\mathrm{c}$ was similar to transect $1 \mathrm{a}-\mathrm{c}$ (Figs. $1 \& 2 \mathrm{a}, \mathrm{c}$ ), while the seafloor temperature and salinity decreased from 6 to $2{ }^{\circ} \mathrm{C}$ and from 35 to 34.2 , respectively (Fig. $2 b, d$ ). The deep sill separating the Outer basin from the Mid basin appeared to be a transition point between these 2 seafloor water masses. Both surface and seafloor temperature decreased to $2^{\circ} \mathrm{C}$ at Stns $3 \mathrm{a}-\mathrm{C}$ and to $1^{\circ} \mathrm{C}$ at Stns $4 a-b$. Similarly, the salinity decreased to 34.1 at Stns $4 a-b$. Chl a concentration in the Mid basin displayed a cross-fjord gradient, with the highest concentrations recorded in the Bays and along the western side of the fjord. The highest surface concentrations and highest overall level of chl a was recorded at

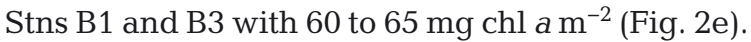

The Inner basin was cold and less saline compared to the other 2 basins. The water column temperature was 0 and $-1{ }^{\circ} \mathrm{C}$ at Stns $5 \mathrm{a}$ and $5 \mathrm{~b}$, respectively, while the salinity was 34 at Stn $5 \mathrm{a}$ and 33.8 at Stn $5 \mathrm{~b}$ (Fig. 2a,c). The chl a concentration was similar to the

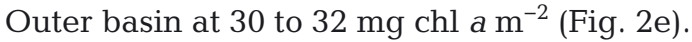
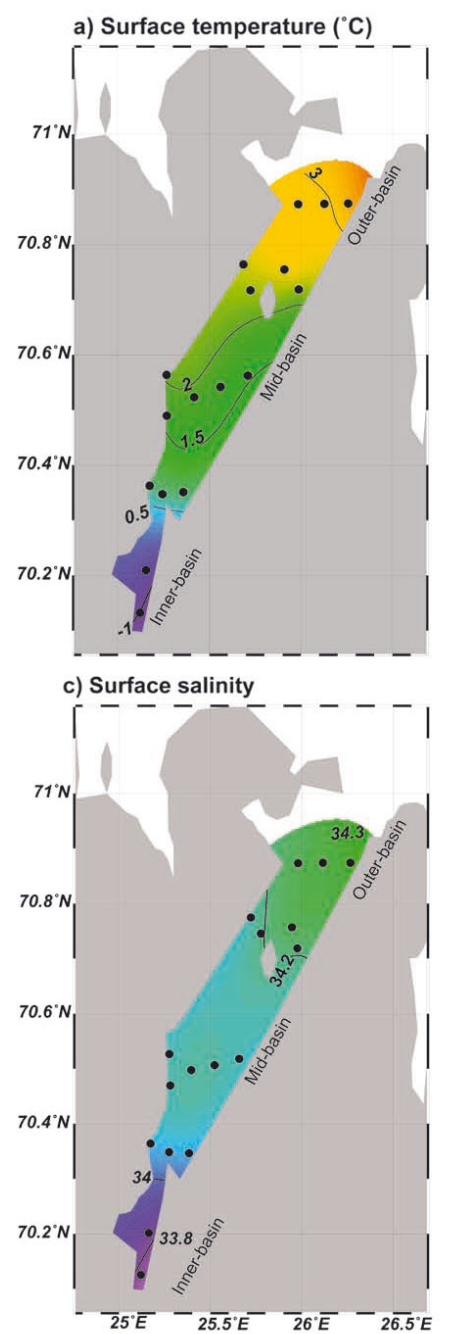
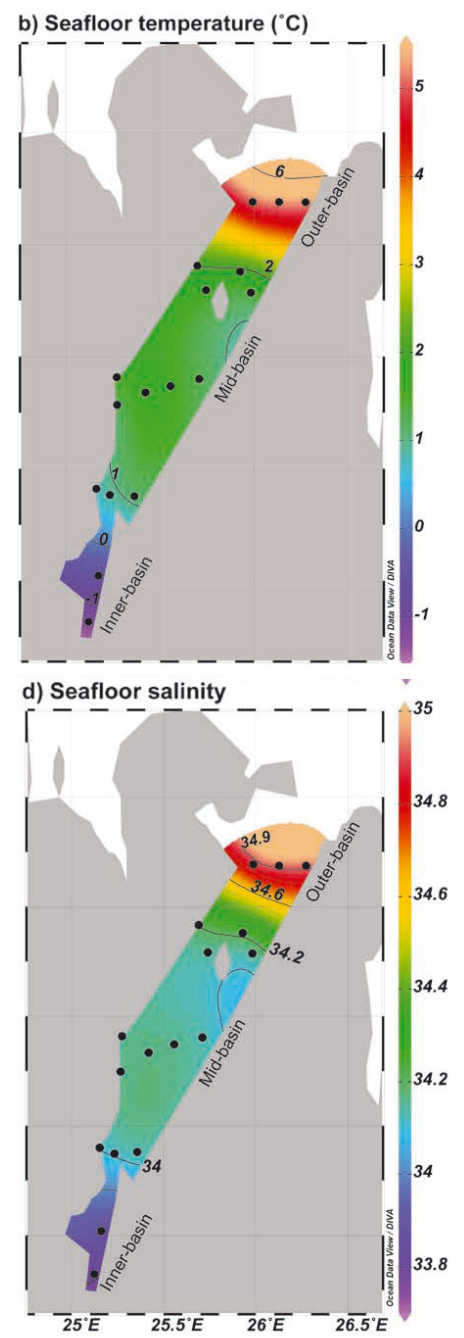

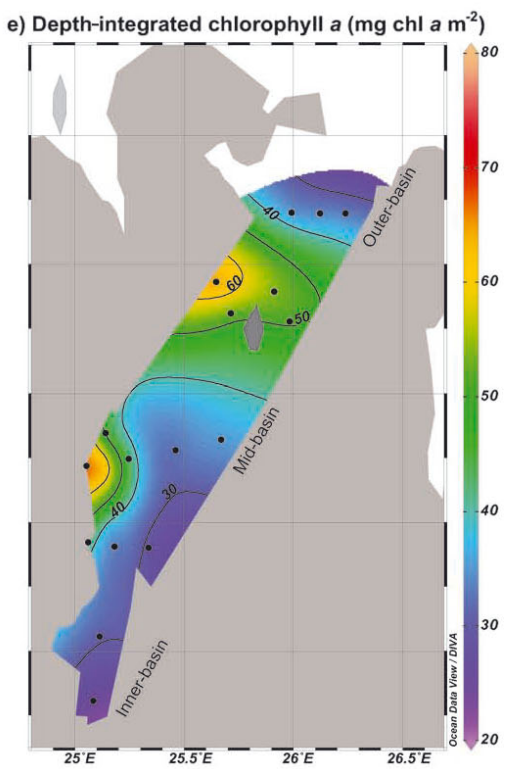

Fig. 2. Horizontal distribution of (a) surface temperature, (b) seafloor temperature, (c) surface salinity, (d) seafloor salinity and (e) surface chl a during April 2013 in Porsangerfjord. Sampling stations are marked with a black dot (see Fig. 1 for station names) 
Table 1. Composition and mean $( \pm \mathrm{SD})$ abundance of meroplankton at the 4 geographical areas in Porsangerfjord. Data are based on $\mathrm{n}=3$ samples in the Outer basin, 2 samples in the Inner basin, 6 samples in the Mid basin and 4 samples in the Bays. Standard deviation is not included when larvae were found in only 1 sample; (-) indicates 0 ind. $\mathrm{m}^{-3}$

\begin{tabular}{|c|c|c|c|c|}
\hline \multirow[t]{2}{*}{ Taxa } & \multicolumn{4}{|c|}{ Abundance (ind. $\mathrm{m}^{-3}$ ) } \\
\hline & Outer basin & Inner basin & Mid basin & Bays \\
\hline \multicolumn{5}{|l|}{ Arthropoda } \\
\hline Paralithodes camtschaticus zoea & - & - & $0.05 \pm 0.02$ & $3 \pm 5$ \\
\hline Hyas spp. zoea & - & - & $0.04 \pm 0.02$ & $0.2 \pm 0.1$ \\
\hline Pagurus pubescens zoea & - & 0.06 & $0.1 \pm 0.07$ & $1.3 \pm 0.2$ \\
\hline Pagurus bernhardus zoea & - & - & 0.2 & 0.03 \\
\hline Cirripedia early naupliar stage & - & 0.04 & $13 \pm 9$ & $43 \pm 60$ \\
\hline $\begin{array}{l}\text { Balanus crenatus (later } \\
\text { naupliar stage) }\end{array}$ & $1.2 \pm 1.4$ & $2 \pm 1$ & $22 \pm 13$ & $175 \pm 153$ \\
\hline Balanus spp. (later naupliar stage) & $5 \pm 4$ & $5 \pm 0.3$ & $125 \pm 98$ & $981 \pm 873$ \\
\hline Cirripede cypris & 0.1 & - & - & - \\
\hline \multicolumn{5}{|l|}{ Annelida } \\
\hline Polychaete unidentified & - & 0.04 & 1 & - \\
\hline Polychaete trochophore & 0.1 & - & 0.5 & 3 \\
\hline Polychaete metatrochophore & - & - & 0.84 & 31 \\
\hline Laonice cirrata metatrochophore & $4 \pm 3$ & $35 \pm 21$ & $24 \pm 20$ & $176 \pm 82$ \\
\hline Dipolydora sp. metatrochophore & $0.2 \pm 0.03$ & $0.04 \pm 1.3$ & $1.26 \pm 1.3$ & $48 \pm 16$ \\
\hline Scolelepis sp. metatrochophore & 0.2 & 0.15 & $0.27 \pm 0.1$ & $1 \pm 0.4$ \\
\hline Owenia sp. metatrochophore & - & - & 0.15 & - \\
\hline Pectinaria sp. metatrochophore & - & - & $0.5 \pm 0.5$ & $44 \pm 47$ \\
\hline \multicolumn{5}{|l|}{ Echinodermata } \\
\hline Pluteus unidentified & $1.1 \pm 1.5$ & - & $1.3 \pm 1.6$ & $3 \pm 2$ \\
\hline Ophiuroidea pluteus & $5 \pm 7$ & - & $1.7 \pm 1.1$ & 2 \\
\hline Ophiothrix pluteus & $1.5 \pm 0.3$ & - & $0.2 \pm 0.2$ & - \\
\hline Echinoidea pluteus & $0.1 \pm 0.09$ & - & $4.4 \pm 5.2$ & - \\
\hline Asteriodea bipinnaria & 0.07 & - & - & - \\
\hline Asteriodea juvenile & - & 0.2 & - & - \\
\hline \multicolumn{5}{|l|}{ Mollusca } \\
\hline Gastropod veliger & $0.3 \pm 0.2$ & $8 \pm 3$ & $2 \pm 1$ & $10 \pm 4$ \\
\hline Nudibranch veliger & $1 \pm 0.2$ & $5 \pm 2$ & $2 \pm 1$ & $14 \pm 5$ \\
\hline Velutina sp. veliger & $0.06 \pm 0.08$ & 0.04 & $0.1 \pm 0.09$ & 1 \\
\hline \multicolumn{5}{|l|}{ Unidentified } \\
\hline Trochophore & 0.03 & $2 \pm 1$ & $0.5 \pm 0.5$ & $37 \pm 6$ \\
\hline \multicolumn{5}{|l|}{ Chordata } \\
\hline Ascidiacea tadpole larvae & 0.02 & - & 0.2 & - \\
\hline \multicolumn{5}{|l|}{ Sipuncula } \\
\hline Sipuncula & - & 0.04 & - & - \\
\hline \multicolumn{5}{|l|}{ Nemertea } \\
\hline Pillidium & 0.03 & - & - & - \\
\hline \multicolumn{5}{|l|}{ Cnidaria } \\
\hline Cerianthus sp. & - & 0.04 & 0.1 & - \\
\hline Total & $21 \pm 11$ & $58 \pm 23$ & $203 \pm 1221$ & $1573 \pm 1159$ \\
\hline
\end{tabular}

Meroplankton were present at all stations, and cluster analysis based on the Bray-Curtis dissimilarity matrix showed 3 significantly different clusters of stations (Fig. 3). The Bay stations made up the first cluster (bootstrap resampling, p = 0.02), Mid basin stations the second cluster (bootstrap resampling, p = 0.02) and the Inner and Outer basin stations in the third cluster (bootstrap resampling, $\mathrm{p}=0.05)$. There were 2 exceptions to this trend: Stn 2b grouped with the Inner/ Outer basin cluster while Stn 2a grouped with the Bay stations.

The total abundance of meroplankton differed significantly between the 3 basins (K-W, $\mathrm{p}=0.005)$. The Inner/Outer basins had a significantly lower abundance than both the Bay stations and the Mid basin (K-W Dunn's, $\mathrm{p}=0.02$ and $\mathrm{p}=0.03$, respectively). The Bay stations did not significantly differ from the Mid basin (K-W Dunn's, p = 0.9). The Outer and Inner basins contained the lowest abundance of meroplankton, ranging from 5 to 100 ind. $\mathrm{m}^{-3}$ (Fig. 4a, Table 1). The Mid basin contained higher abundances (101 to 1001 ind. $\mathrm{m}^{-3}$ ), increasing in numbers from Stns 2a-c to $4 \mathrm{a}-\mathrm{b}$ (Fig. 4a). The Bay stations contained the highest abundances (1001 to 3000 ind. $\mathrm{m}^{-3}$ ), with the highest abundance (3037 ind. $\mathrm{m}^{-3}$ ) recorded at Stn B3.

The community structure was significantly different between the Bay stations, Mid basin and Inner/Outer basin (PERMANOVA, $\mathrm{R}^{2}=0.5, \mathrm{p}=$ 0.005). SIMPER analysis identified the greatest dissimilarity in composi-

\section{Meroplankton community composition and distribution}

A total of 32 morphologically different larval types were identified, belonging to 23 taxa within 8 phyla (Table 1). Of these, 6 taxa belonged to Arthropoda, 5 to Annelida, 4 to Echinodermata, 3 to Mollusca and a single taxon each to Chordata, Nemertea, Cnidaria and Sipuncula. Cirripedia was the dominant and most prevalent meroplanktonic taxon within the fjord (Table 1). tion to be between the Bays and the Inner/Outer basins (average dissimilarity 62\%), followed by the Inner/Outer basins versus the Mid basin (average dissimilarity $47 \%$ ) and the Bays versus Mid basin (average dissimilarity $42 \%$ ) (Table 2). Furthermore, SIMPER analysis determined that the main organisms responsible for this difference in community structure between these areas were primarily the cirripeds Balanus spp. and $B$. crenatus, the polychaete Laonice cirrata and unidentified trochophores (Table 2). 


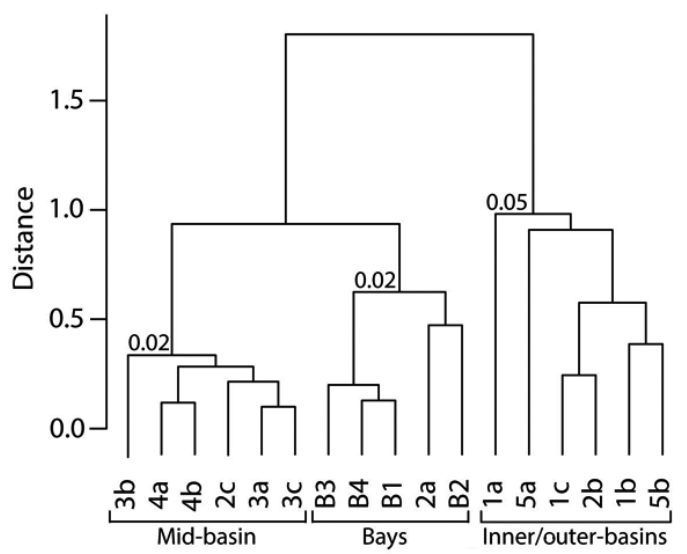

Fig. 3. Bray-Curtis cluster analysis based on fourth-root transformed meroplankton abundance data from April 2013 at all sampled stations in Porsangerfjord. Three significant clusters of stations were indicated: Bays (Stns B1 to B4 and 2a), Mid basin (Stns 2c, 3a-c, 4a and 4b), and Inner/Outer basins $(1 a-c, 2 b, 5 a$ and $5 b)$. Significant p-values for each cluster, calculated by multi-scale bootstrap resampling, are indicated above the nodes

The composition and relative abundance of the main meroplanktonic taxa varied between basins and stations (Fig. 4b). The 2 Inner basin stations differed, with Stn 5a dominated by polychaetes and Stn $5 b$ by Gastropoda. The Outer basin had a more varied community consisting of Echinodermata, Polychaeta and Cirripedia. The Mid basin and Bay stations were dominated by Cirripedia followed by
Polychaeta. Dominant cirripede nauplii were Balanus spp. (a combination of B. balanus and Semibalanus balanoides), $B$. crenatus and unidentified first stage nauplii (Table 1). They represented between 40 and $91 \%$ of the community in the Mid basin and Bays (Fig. 3b). Polychaetes were the second most prevalent taxon and was represented by a high number of taxa, with L. cirrata, Dipolydora sp. and Pectinaria sp. dominating (Table 1). They represented between 11 and $72 \%$ of the community in the fjord and contributed the most at Stns 5a and B2 (primarily L. cirrata). Gastropoda were present at all stations but contributed less overall ( 0.7 to $54 \%$ ) and were represented by unidentified prosobranch veligers and nudibranch veligers. They contributed significantly at Stns 5b (54\%) and $1 \mathrm{~b}(28 \%)$. Echinoderms were found at a majority of stations and contributed highly in the Outer basin, particularly at Stn 1a (44\%). Pluteus larvae of ophiuroid and echinoid origin were the most prevalent within this taxon. However, both of these taxa were completely lacking in the Inner basin. The category 'Other organisms' did not contribute much in relative abundances within the fjord; their greatest contribution was found at Stn B2 (primarily unidentified trochophores). Although present in low numbers, decapod zoeae were found at all stations within the Mid basin and Bays. Of these, Paralithodes camtschaticus, Hyas sp. and Pagurus pubescens were the most prevalent (Table 1).
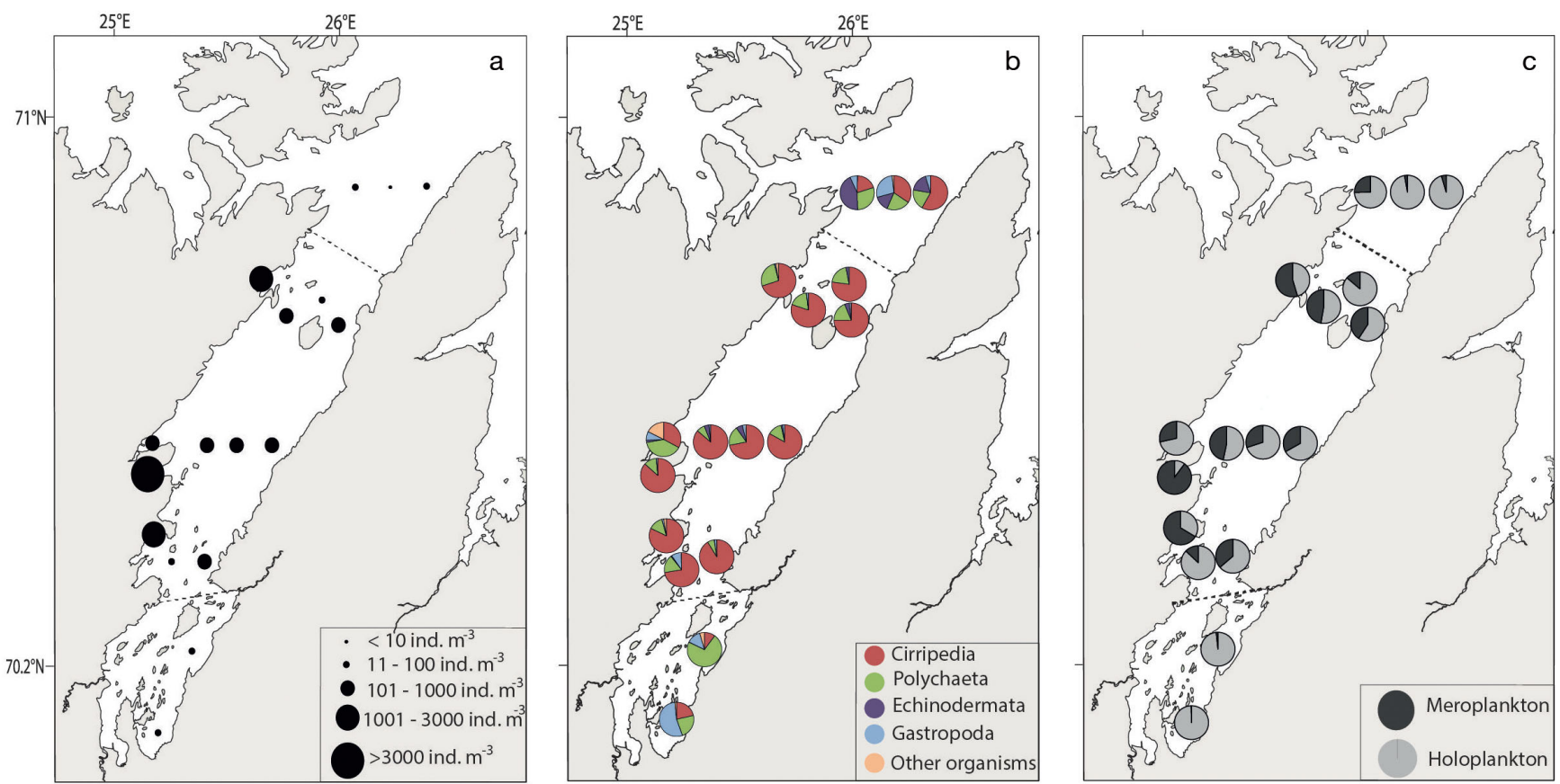

Fig. 4. (a) Total abundance of meroplankton, (b) relative abundance and composition of meroplankton and (c) relative abundance of meroplankton and holoplankton in Porsangerfjord, April 2013 
Table 2. SIMPER results performed on fourth-root transformed meroplankton abundance (ind. $\mathrm{m}^{-3}$ ). Av.Diss. = average dissimilarity, Av.Contr. = average contribution to the overall dissimilarity between geographical areas; Cum.Contr. $=$ ordered cumulative contribution to the difference between geographical areas. Only taxa contributing up to $75 \%$ of the cumulative contribution are presented

\begin{tabular}{|c|c|c|}
\hline & $\begin{array}{l}\text { Av.Contr. } \\
(\%)\end{array}$ & $\begin{array}{c}\text { Cum.Contr. } \\
(\%)\end{array}$ \\
\hline \multicolumn{3}{|c|}{ Mid basin vs. Bays (Av.Diss: 42\%) } \\
\hline Balanus spp. & 4.6 & 11 \\
\hline Trochophore & 3.8 & 20 \\
\hline Balanus crenatus & 3.5 & 28.4 \\
\hline Pectinaria sp. & 3.3 & 36.3 \\
\hline Laonice cirrata & 3.2 & 43.9 \\
\hline Dipolydora sp. & 2.9 & 50.8 \\
\hline Cirripedia early nauplii & 2.7 & 57.2 \\
\hline Nudibranch veliger & 1.8 & 61.6 \\
\hline Pluteus unidentified & 1.8 & 65.9 \\
\hline Paralithodes camtschaticus & 1.8 & 70.1 \\
\hline \multicolumn{3}{|c|}{ Outer/Inner basin vs. Bays (Av.Diss: 62\%) } \\
\hline Balanus spp. & 10.4 & 16.8 \\
\hline Balanus crenatus & 5.4 & 25.6 \\
\hline Laonice cirrata & 5.4 & 34.3 \\
\hline Trochophore & 4.5 & 41.5 \\
\hline Cirripedia early nauplii & 4.4 & 48.6 \\
\hline Pectinaria sp. & 4.3 & 55.6 \\
\hline Dipolydora sp. & 3.3 & 60.9 \\
\hline Paralithodes camtschaticus & 3.0 & 65.7 \\
\hline Pluteus unidentified & 2.3 & 69.4 \\
\hline \multicolumn{3}{|c|}{ Outer/Inner basin vs. Mid basin (Av.Diss: $47 \%$ ) } \\
\hline Balanus spp. & 7.6 & 16.2 \\
\hline Cirripedia early nauplii & 5.3 & 27.5 \\
\hline Balanus crenatus & 3.5 & 35.0 \\
\hline Ophiuroidea pluteus & 2.6 & 40.6 \\
\hline Laonice cirrata & 2.6 & 46.2 \\
\hline Echinoidea pluteus & 2.5 & 51.6 \\
\hline Dipolydora sp. & 2.3 & 56.4 \\
\hline Pluteus unidentified & 1.9 & 60.3 \\
\hline Trochophore & 1.8 & 64.1 \\
\hline Ophiophrix pluteus & 1.7 & 67.7 \\
\hline
\end{tabular}

The proportion of meroplankton in the total zooplankton abundance was low in the Inner and Outer basins; they represented between 0.5 and $2 \%$ of the zooplankton community in the Inner basin and between 3 and $25 \%$ in the Outer basin (Fig. 4c). In the Mid basin, where the total abundance of meroplankton was higher, meroplankton represented between 13 and $48 \%$ of the zooplankton community. The Bay stations had the highest relative abundance of meroplankton, representing between 30 and $90 \%$ of the community.

\section{Meroplankton communities related to environmental factors}

Forward-selection on environmental variables identified seafloor salinity and chl a as significant keys to explaining meroplankton distributions ( $\mathrm{p}<$ 0.05) (see Table S2 in the Supplement at www.intres.com/articles/suppl/b026p185_supp.pdf). However, note that in the first selection round it appeared that seafloor temperature was a covariate to seafloor salinity and may be of importance in the observed spatial differences (Table S2). The resulting ordination axes explained $21.8 \%$ of total variance in the meroplankton dataset and significantly explained the variance (ANOVA, p < 0.05) (Table 3). Axis I significantly explained the variance in the dataset (Table 3 ) and accounted for $15 \%$ of the total variance and $69 \%$ of the explainable variation. Axis II was not significant (Table 3 ; only explaining $7 \%$ of the total variance and $31 \%$ of the explainable variance). Together, the 2 environmental variables significantly explained the total variance (ANOVA, $F=1.9, \mathrm{p}=$ 0.002). In the CCA ordination plot (Fig. 5a), stations clustered in a similar fashion to the Bray-Curtis clusters, indicating strong groups. The Outer basin stations correlated with waters of higher sea floor salinity (Fig. 5). The Inner basin stations grouped according to cold and low saline water masses and low chl a. A majority of the Mid basin transects were associated with high similarity and intermediate water masses. There was a slight tendency for Bay stations to be associated with higher chl $a$, indicating higher phytoplankton concentration at these stations.

Cirripede cypris, pilidium, asteroid bipinnaria and ophiothrix pluteus larvae were associated with higher seafloor salinities, characteristic of Stns 1a, 1b and 1c (Fig. 5b). Juvenile asterioids, Sipuncula, Cerianthus sp. and unidentified early polychaete larvae were associated with the low salinity water masses at Stns 5a and 5b. A majority of taxa were placed in the center of the plot as they were found in a majority of samples. There was a strong link between total abundance of meroplankton (isolines in Fig. 5b) and chl a concentration; the highest meroplankton abundances correlated positively with the highest chl a concentrations. Late stage polychaetes and Balanus spp. were associated with water masses with high chl a (Fig. 5).

\section{DISCUSSION}

\section{Meroplankton abundance and composition}

The composition and abundance of meroplankton in Porsangerfjord during April 2013 showed significant differences between basins and regions within the fjord (Outer/Inner basin, Mid basin and Bays). 
The overall meroplanktonic composition contained prominent members characteristic of late winter and spring in high-latitude fjord and coastal areas, suggesting that spring spawning had initiated within the fjord (Falk-Petersen 1982, Kuklinski et al. 2013, Silberberger et al. 2016, Stübner et al. 2016, Michelsen et al. 2017). The 3 dominant taxa (Cirripedia, Polychaeta and Echinodermata) contain late winter and spring spawning representatives, capable of producing large amounts of propagules (Young et al. 2002).

Cirripede nauplii, the dominant component in the meroplanktonic community, ranged from 2 to 2700 ind. $\mathrm{m}^{-3}$ (see Table S3 in the Supplement at www. int-res.com/articles/suppl/b026p185_supp.pdf). This is lower than the density of 4000 ind $\mathrm{m}^{-3}$ found in the sub-Arctic Balsfjord, Norway (Falk-Petersen 1982). Moreover, Kwasniewski et al. (2013) found the abundance of nauplii to vary between 16 and 15222 ind. $\mathrm{m}^{-3}$ during a $4 \mathrm{mo}$ spring study in the high-Arctic Kongsfjord, Svalbard. In contrast, Stübner et al. (2016) found peak densities in the range of 25000 to 30000 ind. $\mathrm{m}^{-3}$ in May using a WP2 equipped with a $63 \mu \mathrm{m}$ mesh net in the high-Arctic Adventfjord, Svalbard. The use of a coarser mesh size in our study may have under-sampled cirripede nauplii and other small sized organisms such as trochophores, bivalve veligers and bryozoan cyphonautes. Riccardi (2010) reported an abundance loss of $30 \%$ for small bivalves and polychaetes when comparing $200 \mu \mathrm{m}$ mesh sam-
Table 3. ANOVA test for the significance of environmental variables in the canonical correspondence analysis (CCA) (Fig. 5). ${ }^{*} \mathrm{p}<0.05{ }^{* *} \mathrm{p}<0.01 ;{ }^{* * *} \mathrm{p} \leq 0.001$

\begin{tabular}{|lcc|}
\hline Variable & $F$ & $\mathrm{p}$ \\
\hline All variables & 2.0 & $0.002^{* *}$ \\
Seafloor salinity & 2.2 & $0.001^{* * *}$ \\
Chl a & 1.5 & $0.04^{*}$ \\
& & \\
Axis 1 & 2.7 & $0.001^{* * *}$ \\
Axis 2 & 1.2 & 0.2 \\
\hline
\end{tabular}

ples with $80 \mu \mathrm{m}$ samples. Despite such sampling artefacts, the first 2 studies used a comparable mesh size to our study and thus variation in nauplii abundance may reflect regional differences in abundance of benthic adults, reproductive output, timing and the dynamic spatial distribution displayed by pelagic organisms.

The spatial dynamics of meroplankton are subject to advection from (Mileikovsky 1968) and retention in the area of release (Wing et al. 1998, Lamare \& Barker 1999). Because the present study merely provided a snapshot of the spatial patterns in meroplankton community and abundance and did not look at the vertical distribution of larvae nor the hydrodynamics within Porsangerfjord, it is difficult to say from where the larvae originate. However, a
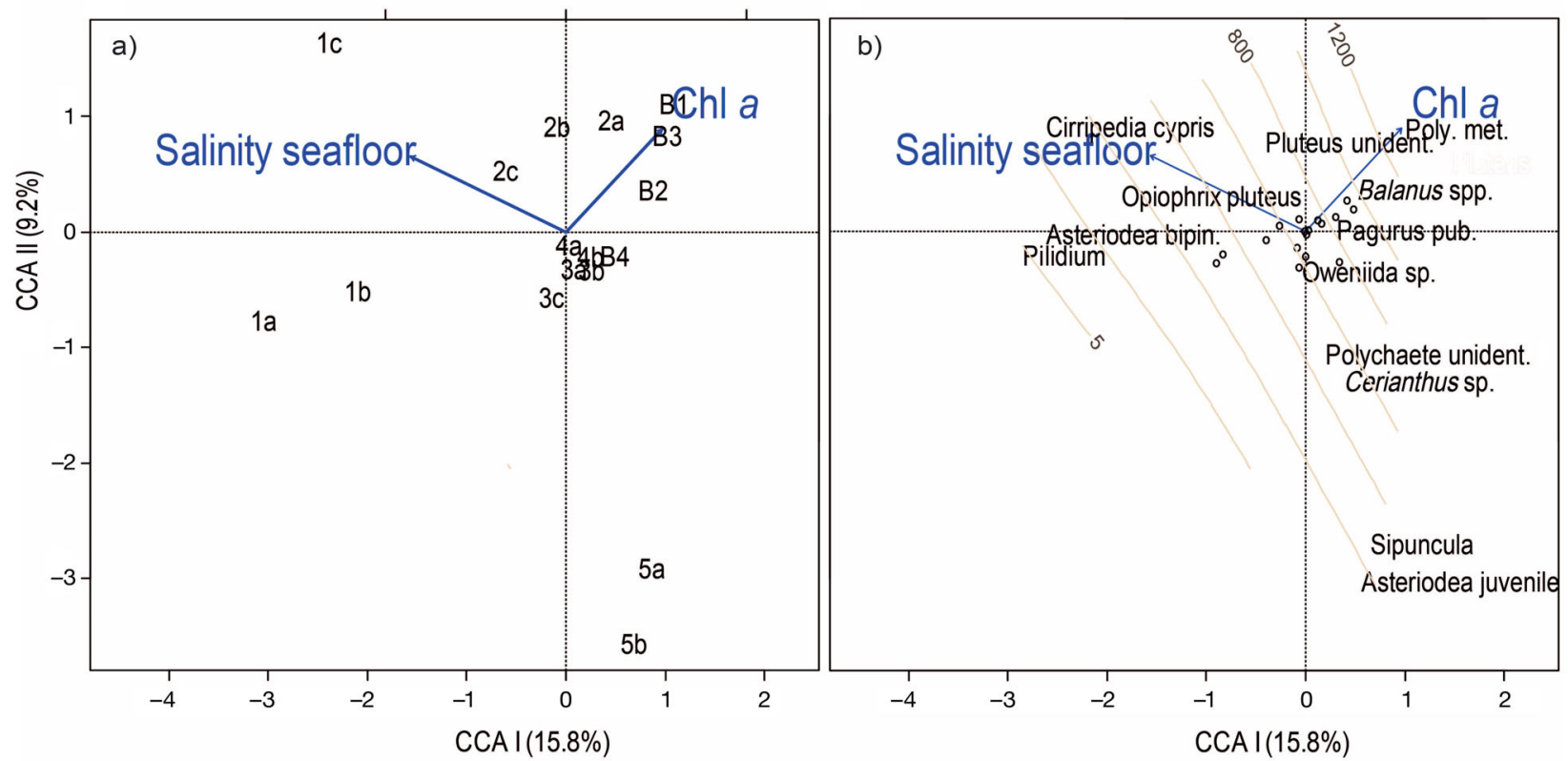

Fig. 5. Canonical correspondence analysis (CCA) on fourth-root transformed compositional data constrained by environmental variables. (a) Ordination plot with stations and (b) ordination plot with species and isolines (brown diagonal lines) displaying total abundance of meroplankton. The eigenvalues in percentage are given for dimensions I and II with a total of $25 \%$ of the variance in the dataset explained. Taxa representing $>1 \%$ of the variation are presented with full names; the remaining with an open circle. Poly. met. $=$ Polychaete metatrochophore. Numbers and letters refer to station names; see Fig. 1 for locations 
number of modeling studies have focused on the hydrodynamic patterns within the fjord (Svendsen 1991, Pedersen et al. 2005, Stramska et al. 2016) and modeled the drift of crab zoea (Pedersen et al. 2006) and fish eggs in surface waters (Myksvoll et al. 2012). This body of work may aid in explaining some of the spatial patterns observed. In a high-resolution simulation of cod eggs drifting in the upper $1 \mathrm{~m}$ of Porsangerfjord, Myksvoll et al. (2012) identified the fjord sills as physical barriers restricting eggs originating in the Mid basin from entering neighboring basins. Such barriers may be one cause for the different meroplankton compositions in the 3 basins, separating the communities to some extent. The Outer basin is characterized by a mixture of water masses (NCC and fjord water) and experiences a high level of advection out to the coast (Pedersen et al. 2005). It is possible that larvae residing in this basin are a mixture of larvae originating from the NCC and from within the fjord and that they experience rapid flushing to the coast, leading to a mixed community and low abundance. Due to the strong outflow current of surface water along the eastern shore (Hegseth et al. 1995, Pedersen et al. 2005), the high relative abundance of late staged cirripede nauplii and cyprids at the eastern station of the Outer basin (Stn 1c) may originate from within the fjord. The many small eddies and gyres characterizing the Mid basin contributes to mixing and distributing larvae released in the basin (Svendsen 1991, Pedersen et al. 2006, Myksvoll et al. 2012), resulting in the homogenous composition of meroplankton across transects. Myksvoll et al. (2012) also modeled the trajectories of eggs released from Bay Stns B2 and B3 and found that eggs released at Stn B2 were rapidly distributed in the Mid basin, while eggs from Stn B3 were retained within the Bay. The high concentration of meroplankton at Stn B3 may therefore be caused by a higher retention rate of larvae residing in the upper water column.

Depending on the level of larval transport within the fjord, the spatial abundance and composition of meroplankton can reflect the local distribution and composition of parental populations. Although we did not examine the benthic community, a recent paper on benthic production within Porsangerfjord found no significant difference in benthic adult abundance between the 3 basins (Fuhrmann et al. 2015). Moreover, they found that Polychaeta are the most prevalent and abundant macrobenthic organisms, and adult representatives of the identified larvae reside on soft-bottom localities within all 3 basins (e.g. Spionidae, Oweniidae and Pectinariidae in Fuhr- mann et al. 2015). Similarly, gastropods are found in all basins but at lower densities (Fuhrmann et al. 2015). These findings correspond well with the homogenous distribution of larvae belonging to both taxa in this study. Adult cirripedes are located primarily on hard bottom in the littoral and sublittoral zone (T. Pedersen pers. obs.), which may result in the highest concentration of nauplii being found at the Bay stations due to similar environmental variables. The shallow depth and closer proximity to shore decreases the distance between spawning adults and the pelagic, resulting in a regular supply of propagules to the water column at these stations. Finally, adult echinoderms are found within the whole fjord, but their highest densities and biomass have been located in the Outer and Inner basin, where ophiuroids dominate in the former and the mud star Ctenodiscus crispatus in the latter (Fuhrmann et al. 2015, L. L. Jørgensen pers. comm.). Thus, the higher presence of Ophiuroidea and ophiothrix plutei in the Outer basin may correspond with adult distribution within the fjord.

Although the highest total abundance and relative abundance of meroplankton in the zooplankton are found in the Bays, their relative abundance was high at many Mid basin stations (up to $47 \%$ ) despite deeper depths and greater distance from shore. It is common for meroplankton abundance and relative contribution to the mesozooplankton community to be high within fjords, estuaries and bays (Fetzer et al. 2003, Stübner et al. 2016, Michelsen et al. 2017) and may be attributed to fine-scale distributions of eddies and retention properties acting on both meroplanktonic and holoplanktonic organisms. Furthermore, studies on the seasonal dynamics of zooplankton have shown a periodic (Smidt 1979, Questel et al. 2013, Michelsen et al. 2017) or even a continuous (Stübner et al. 2016) dominance of meroplankton through spring and summer at high latitudes. Thus, despite the variable nature of meroplankton abundance, distribution and seasonality in fjords, they can contribute highly to the zooplankton community and may thereby play a role as phytoplankton grazers and prey.

\section{Meroplankton succession along the environmental gradient}

The strongly seasonal environment within Porsangerfjord has been found to result in a significant change in the composition of meroplanktonic taxa present in the water column through the year 
(Michelsen et al. 2017). Four seasonal compositions occur within the fjord (winter, spring, early summer and late summer), and the transition between winter and spring is particularly strong due to an increase in chl $a$ and photoperiod (Michelsen et al. 2017). The clear differences in water mass properties between the 3 basins in this study may therefore affect the spawning and hatching mechanisms of local benthic adults, resulting in some of the observed spatial differences in meroplankton composition.

In the Inner basin, sub-zero temperatures and low salinity can act as limiting factors for species requiring higher temperatures or temperature thresholds to spawn (Olive 1995). The complete absence of pluteus larvae in this basin, despite adult representatives residing here, suggest that some spawning cue had not been reached for these adults. The exact environmental cues required for these taxa to spawn is disputed, but direct contact with phytoplankton cells and their heat-stable metabolites during spring is suggested to be a trigger for some echinoids and ophiuroids (Starr et al. 1990, 1993). As chl a concentrations were low in the Inner basin, adults may not have come in contact with adequate amounts of phytoplankton at the time of sampling. Yet, chl a concentrations in this basin were comparable with stations in the Outer basin. A combination of photoperiod and temperature are alternative spawning triggers for some echinoderms (Olive 1995). Considering that day length is the same along the fjord, it is likely that temperature and/or salinity are additional limiting factors for spawning in the Inner basin. In temperate, boreal and sub-Arctic areas, pluteus larvae appear in the water column between March and April (Thorson 1946, Falk-Petersen 1982, Highfield et al. 2010, Silberberger et al. 2016) while a later appearance (April to May) is observed in the Arctic due to a later onset of the phytoplankton bloom (Kwasniewski et al. 2013, Stübner et al. 2016). A less developed phytoplankton bloom and cooler temperatures in the Inner basin may cause later spawning for these taxa. The low abundance of meroplankton and high presence of gastropod veligers within this basin correspond with the late winter meroplankton community in Porsangerfjord (Michelsen et al. 2017) and in the Arctic in general (Falk-Petersen 1982, Hirche \& Kosobokova 2011, Arendt et al. 2013, Stübner et al. 2016). Prosobranch and nudibranch veligers are present in the water column during a majority of the year within Porsangerfjord and other high-latitude coastal areas (Falk-Petersen 1982, Kuklinski et al. 2013, Michelsen et al. 2017). Thus, the benthic community in the Inner basin may have been in a late winter to early spring spawning phase at the time of sampling.

Adult cirripedes belonging to Semibalanus balanoides initiate larval release when coming in direct contact with phytoplankton cells and suspended particles at the onset of the spring phytoplankton bloom in March and April (Barnes 1962, Starr et al. 1991, Gyory et al. 2013). Thus, although the chl a concentration varied between stations, the environmental triggers required for adult cirripedes to release their larvae are likely to have been reached in the whole fjord. The low abundance of cirripede nauplii in the Inner basin supports the indication of a less advanced phytoplankton bloom within this basin, while the high abundance and relative abundance of nauplii in the Bays correlates with an advanced spring bloom at these stations. Similar correlations have been detected in other organisms producing planktotrophic larvae such as polychaetes and echinoderms (Kuklinski et al. 2013, Stübner et al. 2016, Michelsen et al. 2017). A high relative abundance of cirripede nauplii in both the meroplanktonic and the holoplanktonic community is a common indicator of spring in coastal areas (Smidt 1979, Kwasniewski et al. 2013, Silberberger et al. 2016, Stübner et al. 2016), suggesting that benthic adults in the Mid basin and Bays were in a spring spawning phase.

This study demonstrated the importance of environmental variables on the meroplanktonic community. Sub-zero temperatures and low chl a values in the Inner basin are likely to cause delayed larval release in benthic adults compared to the rest of the fjord. The typical spring community with high proportions of cirripede in the Bays and mid-fjord correlated with higher chl a values, while the Outer basin is likely influenced by advection and coastal waters bringing in organisms from outside the fjord. The significant spatial differences in meroplankton abundance and composition suggest that there is some separation and retention between some subareas of the fjord. Furthermore, the high contribution of meroplankton to the mesozooplankton community in parts of the fjord mean that they could be important grazers, competitors and prey for other organisms in such coastal systems. To further understand their potential role in the pelagic food web of sub-Arctic fjords, future studies need to focus on identifying larvae to species level, their nutritional mode (planktotrophy vs. lecithotrophy), prey preferences and ingestion rates and finally the predation rate on meroplanktonic larvae by potential predators (e.g. fish, ctenophores). 
Acknowledgements. We thank the crew of RV 'Johan Ruud' and Emma Källgren for participation and help during fieldwork. Furthermore, we thank 3 reviewers and the editor for highly constructive comments that improved the manuscript considerably. We also acknowledge the financial support provided by UiT The Arctic University of Norway.

\section{LITERATURE CITED}

Andersen OGN (1984) Meroplankton in Jørgen Brønlund Fjord, North Greenland. Medd Gronl Biosci 12:1-29

Anderson MJ (2001) A new method for non-parametric multivariate analysis of variance. Austral Ecol 26:32-46

Arendt KE, Juul-Pedersen T, Mortensen J, Blicher ME, Rysgaard S (2013) A 5-year study of seasonal patterns in mesozooplankton community structure in a sub-Arctic fjord reveals dominance of Microsetella norvegica (Crustacea, Copepoda). J Plankton Res 35:105-120

Barnes H (1962) Note on variations in the release of nauplii of Balanus balanoides with special reference to the spring diatom outburst. Crustaceana 4:118-122

Basedow SL, Eiane K, Tverberg V, Spindler M (2004) Advection of zooplankton in an Arctic fjord (Kongsfjorden, Svalbard). Estuar Coast Shelf Sci 60:113-124

Clough LM, Ambrose WG Jr, Ashjian CJ, Piepenburg D, Renaud PE, Smith SL (1997) Meroplankton abundance in the Northeast Water Polynya: insights from oceanographic parameters and benthic abundance patterns. J Mar Syst 10:343-357

Eilertsen HC, Frantzen S (2007) Phytoplankton from two sub-Arctic fjords in northern Norway 2002-2004. I. Seasonal variations in chlorophyll $a$ and bloom dynamics. Mar Biol Res 3:319-332

Eilertsen HC, Skarðhamar J (2006) Temperatures of north Norwegian fjords and coastal waters: variability, significance of local processes and air-sea heat exchange. Estuar Coast Shelf Sci 67:530-538

Eilertsen HC, Falk-Petersen S, Hopkins CCE, Tande K (1981) Ecological investigations on the plankton community of Balsfjorden, northern Norway. Sarsia 66:25-34

Falk-Petersen IB (1982) Ecological investigations on the zooplankton community of Balsfjorden, northern Norway-planktonic eggs and larvae from March 1978 to February 1980. Sarsia 67:69-78

Fetzer I (2003) Distribution of meroplankton in the southern Kara Sea in relation to local hydrographic pattern. In: Stein R, Fahl K, Fütterer DK, Galimov EM, Stephanets OV (eds) Siberian river run-off in the Kara Sea. Proceedings in Marine Sciences, No. 6, Elsevier Science BV, Amsterdam, p 195-212

Fetzer I, Deubel H (2006) Effect of river run-off on the distribution of marine invertebrate larvae in the southern Kara Sea (Russian Arctic). J Mar Syst 60:98-114

Fuhrmann MM, Pedersen T, Ramasco V, Nilssen EM (2015) Macrobenthic biomass and production in a heterogenic subarctic fjord after invasion by the red king crab. J Sea Res 106:1-13

Gyory J, Pineda J, Solow A (2013) Turbidity triggers larval release by the intertidal barnacle Semibalanus balanoides. Mar Ecol Prog Ser 476:141-151

Hegseth E, Svendsen H, von Quillfeldt C (1995) Phytoplankton in fjords and coastal waters of northern Norway: environmental conditions and dynamics of the spring bloom. In: Skjoldal HR, Hopkins C, Erikstad KE, Leinaas
HP (eds) Ecology of fjords and coastal waters. Elsevier Science BV, Amsterdam, p 45-72

*Highfield JM, Eloire D, Conway DVP, Lindeque PK, Attrill MJ, Somerfield PJ (2010) Seasonal dynamics of meroplankton assemblages at station L4. J Plankton Res 32: 681-691

Hirche HJ, Kosobokova KN (2011) Winter studies on zooplankton in Arctic seas: the Storfjord (Svalbard) and adjacent ice-covered Barents Sea. Mar Biol 158:2359-2376

Kuklinski P, Berge J, McFadden L, Dmoch K and others (2013) Seasonality of occurrence and recruitment of Arctic marine benthic invertebrate larvae in relation to environmental variables. Polar Biol 36:549-560

Kwasniewski S, Walkusz W, Cottier FR, Leu E (2013) Mesozooplankton dynamics in relation to food availability during spring and early summer in a high latitude glaciated fjord (Kongsfjorden), with focus on Calanus. J Mar Syst 111-112:83-96

K Lamare MD, Barker MF (1999) In situ estimates of larval development and mortality in the New Zealand sea urchin Evechinus chloroticus (Echinodermata: Echinoidea). Mar Ecol Prog Ser 180:197-211

Levin LA (2006) Recent progress in understanding larval dispersal: new directions and digressions. Integr Comp Biol 46:282-297

Levin LA, Bridges T (1995) Pattern and diversity in reproduction and development. In: McEdward L (ed) Ecology of marine invertebrate larvae. CRC Press, Boca Raton, FL, p 1-48

Mankettikkara R (2013) Hydrophysical characteristics of the northern Norwegian coast and fjords. PhD thesis, University of Tromsø

Meerhoff E, Tapia FJ, Castro LR (2014) Spatial structure of the meroplankton community along a Patagonian fjordthe role of changing freshwater inputs. Prog Oceanogr 129:125-135

Michelsen HK, Svensen C, Reigstad M, Nilssen EM, Pedersen $\mathrm{T}$ (2017) Seasonal dynamics of meroplankton in a high-latitude fjord. J Mar Syst 168:17-30

Mileikovsky SA (1968) Distribution of pelagic larvae of bottom invertebrates of the Norwegian and Barents Seas. Mar Biol 1:161-167

Mileikovsky SA (1971) Types of larval development in marine bottom invertebrates, their distribution and ecological significance: a re-evaluation. Mar Biol 10:193-213

*Monro K, Marshall DJ (2015) The biogeography of fertilization mode in the sea. Glob Ecol Biogeogr 24:1499-1509

* Myksvoll MS, Sandvik AD, Skarðhamar J, Sundby S (2012) Importance of high resolution wind forcing on eddy activity and particle dispersion in a Norwegian fjord. Estuar Coast Shelf Sci 113:293-304

Neubert MG, Caswell H (2000) Demography and dispersal: calculation and sensitivity analysis of invasion speed for structured populations. Ecology 81:1613-1628

Oksanen J (2015) Multivariate analysis of ecological communities in R: vegan tutorial. http://cc.oulu.fi/ jarioksa/ opetus/metodi/vegantutor.pdf

Olive PJW (1995) Annual breeding cycles in marine invertebrates and environmental temperature: probing the proximate and ultimate causes of reproductive synchrony. J Therm Biol 20:79-90

* Pedersen OP, Zhou M, Tande KS, Edvardsen A (2005) Eddy formation on the coast of north Norway-evidenced by synoptic sampling. ICES J Mar Sc 62:615-628

Pedersen OP, Nilssen EM, Jørgensen LL, Slagstad D (2006) 
Advection of the red king crab larvae on the coast of north Norway - a Lagrangian model study. Fish Res 79: 325-336

Priou P (2015) Associations between herbivorous zooplankton, phytoplankton and hydrography in Porsangerfjord, northern Norway. MSc thesis, UiT The Arctic University of Norway, Tromsø

* Questel JM, Clarke C, Hopcroft RR (2013) Seasonal and interannual variation in the planktonic communities of the northeastern Chukchi Sea during the summer and early fall. Cont Shelf Res 67:23-41

R Development Core Team (2012) R: a language and environment for statistical computing. R Foundation for Statistical Computing, Vienna

Renaud PE, Sejr MK, Bluhm BA, Sirenko B, Ellingsen IH (2015) The future of Arctic benthos: expansion, invasion, and biodiversity. Prog Oceanogr 139:244-257

Riccardi N (2010) Selectivity of plankton nets over mesozooplankton taxa: implications for abundance, biomass and diversity estimation. J Limnol 69:287-296

Schlitzer R (2012) Ocean Data View. http://odv.awi.de (accessed September 2016)

Schlüter M, Rachor E (2001) Meroplankton distribution in the central Barents Sea in relation to local oceanographic patterns. Polar Biol 24:582-592

Shanks A (1995) Mechanisms of cross-shelf dispersal of larval invertebrates and fish. In: McEdward L (ed) Ecology of marine invertebrate larvae. CRC Press, Boca Raton, FL, p 323-367

Shanks AL, Grantham BA, Carr MH (2003) Propagule dispersal distance and the size and spacing of marine reserves. Ecol Appl 13:S159-S169

Silberberger MJ, Renaud PE, Espinasse B, Reiss H (2016) Spatial and temporal structure of the meroplankton community in a sub-Arctic shelf system. Mar Ecol Prog Ser 555:79-93

Smidt ELB (1979) Annual cycles of primary production and of zooplankton at southwest Greenland: with figures of some bottom invertebrate larvae. Medd Gronl Biosci 1: $1-52$

Starr M, Himmelman JH, Therriault JC (1990) Direct coupling of marine invertebrate spawning with phytoplankton blooms. Science 247:1071-1074

Starr M, Himmelman JH, Therriault JC (1991) Coupling of nauplii release in barnacles with phytoplankton blooms: a parallel strategy to that of spawning in urchins and mussels. J Plankton Res 13:561-571

Editorial responsibility: Anna Metaxas,

Halifax, Nova Scotia, Canada
Starr M, Himmelman JH, Therriault JC (1993) Environmental control of green sea urchin, Strongylocentrotus droebachiensis, spawning in the St. Lawrence Estuary. Can J Fish Aquat Sci 50:894-901

Stramska M, Jankowski A, Cieszyńska A (2016) Surface currents in the Porsanger fjord in northern Norway. Pol Polar Res 37:337

Stübner EI, Søreide JE, Reigstad M, Marquardt M, Blachowiak-Samolyk K (2016) Year-round meroplankton dynamics in high-Arctic Svalbard. J Plankton Res 38: 522-536

Sunnset B (2008) Mapping marine life in Porsangerfjorden. Marine Research News No. 9, Institute of Marine Research, Bergen

Suzuki R, Shimodaira H (2015) Package 'pvclust': an R package for hierarchical clustering with p-values. http://stat. sys.i.kyoto-u.ac.jp/prog/pvclust/ (accessed August 2016)

Svendsen H (1991) Preliminary results from a hydrophysical investigation of Porsangerfjord, Altafjord and adjacent coastal waters, June-August 1990. Report of the Geophysical Institute, University of Bergen

Svendsen H (1995) Physical oceanography of coupled fjordcoast systems in northern Norway with special focus on frontal dynamics and tides. In: Skjoldal HR, Hopkins C, Erikstad KE, Leinaas HP (eds) Ecology of fjords and coastal waters. Elsevier Science BV, Amsterdam, p 149-164

Thorson G (1936) The larval development, growth, and metabolism of Arctic marine bottom invertebrates compared with those of other seas. Medd Gronl 100:1-36

Thorson G (1946) Reproduction and larval development of Danish marine bottom invertebrates with special reference to planktonic larvae in the Sound (Øresund). Meddelelser fra Kommissionen for Danmarks fiskeri- og havundersøgelser 4:1-523

Thorson G (1950) Reproductive and larval ecology of marine bottom invertebrates. Biol Rev Camb Philos Soc 25:1-45

*Wassmann P, Svendsen H, Keck A, Reigstad M (1996) Selected aspects of the physical oceanography and particle fluxes in fjords of northern Norway. J Mar Syst 8: 53-71

WWing SR, Botsford LW, Ralston SV, Largier JL (1998) Meroplanktonic distribution and circulation in a coastal retention zone of the northern California upwelling system. Limnol Oceanogr 43:1710-1721

Young CM, Sewell MA, Rice ME (2002) Atlas of marine invertebrate larvae. Academic Press, New York, NY

Submitted: February 20, 2017; Accepted: September 1, 2017 Proofs received from author(s): October 27, 2017 